\title{
A PRESUMPTION AND FOUR BURDENS
}

\section{John E Stannard, Senior Lecturer in Law, Queen's University of Belfast*}

Leading cases can be of different types. One dictionary defines a leading case as "a judicial decision or precedent settling the principles of a branch of law"; 1 another speaks of "cases which have had the most influence in settling the law"; ${ }^{2}$ another of "a judicial decision always regarded as the chief precedent or judicial statement of principle on a particular point". ${ }^{3}$ The third of these definitions is preferable to the first two, for this reason: leading cases may indeed be chief precedents, and they may state principles, but they do not always settle the law. If a choice were to be made as to the leading case of the twentieth century in the field of criminal law and evidence, most people would opt without hesitation for Woolmington $\mathrm{v} D P P^{4}$. At one level, no doubt, this "settled" the criminal law by laying down one of its most fundamental principles, namely the presumption of innocence; yet even after sixty years its implications have still not fully been worked out. The aim of this article is to examine the present status of the presumption of innocence in England and Wales and in Northern Ireland, with reference to the jurisprudence of the courts in the Republic of Ireland and of the European Convention on Human Rights. The current law on the topic can best be expressed in terms of a presumption (the presumption of innocence itself as set out in Woolmington) and four burdens (the so-called exceptions to Woolmington, which are generally termed "burdens" on the defence). We shall see how these different burdens relate to one another, and in doing so we shall ask to what extent, if at all, it is either right or necessary to place a burden on the defence in a criminal trial.

\section{THE PRESUMPTION}

The crucial point at issue in Woolmington, as is well known, was as to the incidence of the burden and standard of proof in a case where the accused admitted killing the deceased but claimed in evidence that it was an accident. In giving his summing-up at Taunton Assizes, Swift $\mathrm{J}$ made use of a statement in Foster's Crown Law which, though penned in 1762, had been adopted as a correct statement of the law by virtually every textbook or abridgement since. ${ }^{5}$ This is what Sir Michael Foster wrote:

\footnotetext{
* This article is based on a paper given to the Annual Conference of the Irish Association of Law Teachers in Killarney at the end of April 1999. I am very grateful to Eoin O'Dell and to Jenny McEwan for their helpful comments on earlier drafts. A version of this article, together with other papers given at the conference, appear in Leading Cases of the Twentieth Century (Round Hall Press, 2000).

1 Jowitt's Dictionary of English Law (2nd ed, 1977).

2 Mozley and Whiteley's Law Dictionary (11th ed, 1993).

3 The Oxford Companion to Law (1980).

4 [1935] AC 462 (HL(E)).

5 [1935] AC 462 at 474.
} 
"In every charge of murder, the fact of killing being first proved, all the circumstances of accident, necessity, or infirmity are to be satisfactorily proved by the prisoner, unless they arise out of the evidence produced against him; for the law presumeth the fact to have been founded in malice, unless the contrary appeareth."6

Having quoted this passage to the jury, the judge concluded his summing-up as follows:

"The Crown has got to satisfy you that this woman...died at the prisoner's hands. They must satisfy you of that beyond any reasonable doubt. If they satisfy you of that, then he has to show that there are circumstances to be found in the evidence which has been given from the witness-box in this case which alleviate the crime so that it is only manslaughter or which excuse the homicide altogether by showing that it was a pure accident." $"$

In sum, the judge was telling the jury: "The accused admits the killing. He claims that it was an accident? Let him prove it!" Upon this basis, Woolmington was convicted and duly sentenced to death. An appeal to the Court of Criminal Appeal failed, which is hardly surprising, given that as we have just seen, the passage in Foster quoted by the judge had been regarded as a correct statement of the law for over a hundred and fifty years. ${ }^{8}$ In any event, said the court, the misdirection, if misdirection it had been, had caused no substantial miscarriage of justice. ${ }^{9}$

The House of Lords, however, took a different view. Giving the unanimous opinion of their Lordships, Viscount Sankey declared that if Sir Michael Foster had meant to say that in cases of accident the burden was on the accused to prove his defence to the satisfaction of the jury, ${ }^{10}$ the statement was wrong and should no longer be followed. The appeal was allowed and the conviction quashed:

"Throughout the web of the English Criminal Law one golden thread is always to be seen, that it is the duty of the prosecution to prove the prisoner's guilt subject to . . . the defence of insanity and subject also to any statutory exception. If, at the end of and on the whole of the case, there is a

6 Folio edition, Clarendon Press, Oxford, 1762 at p 255.

[1935] AC 462 at 473.

8 See Jayasena v $R$ [1970] AC 618 (JCPC) at 625 (Lord Devlin).

9 Section 4 of the Criminal Appeal Act 1907 (now repealed) allowed an appeal to be dismissed on this ground even if there had been a misdirection of the jury.

10 Whether he did mean to say this is open to argument. As Lord Sankey himself pointed out on page 478, the law of evidence at the time was in a very fluid state, and on one interpretation Sir Michael Foster was referring only to an "evidential" burden of the type discussed below at nn 60 - 81: see the comments of Davitt P in McGowan v Carville [1960] IR 330 (HC(I)) at 337 and of Lord Devlin in Jayasena $\vee R$ [1970] AC 628 (JCPC) at 623. This has been the interpretation adopted in the Irish Republic since it was held that the presumption of innocence was protected by the Constitution: see Hardy v Ireland [1994] IR 550 (SC(I)) and O'Leary v Attorney-General [1995] 1 IR 254 (SC(I)): below, nn 43 - 48. 
reasonable doubt, created by the evidence given by either the prosecution or the prisoner, as to whether the prisoner killed the deceased with a malicious intention, the prosecution has not made out the case and the prisoner is entitled to an acquittal. No matter what the charge or where the trial, the principle that the prosecution must prove the guilt of the prisoner is part of the common law of England and no attempt to whittle it down can be entertained." 11

Few people would disagree with the view of Sir John Smith that this was the finest day's work ever done by the House of Lords in the field of criminal law, ${ }^{12}$ even though some would argue that the subsequent side-effects of the case have not been entirely benign. ${ }^{13}$ After all, to impose a burden of proof on the defendant, as was done prior to Woolmington, involves telling a jury or a bench of magistrates that they are to convict even if they think that it is as likely as not that the defendant was innocent, a situation which makes a mockery of the law. ${ }^{14}$ The presumption of innocence has been held by the Supreme Court of the Republic of Ireland to be a principle protected by the Constitution, ${ }^{15}$ and it is also enshrined in Article 6(2) of the European Convention of Human Rights. Woolmington is therefore a case of the highest importance, not only in England and Wales, but throughout the whole island of Ireland. Indeed, it has been described as the foundation of the presumption of innocence for the entire common law world. ${ }^{16}$

\section{THE FOUR BURDENS}

The main controversy centres, not on Woolmington itself, but on the socalled exceptions to it. Even Lord Sankey, as we have seen, had to concede two of these: the defence of insanity, and other "statutory exceptions". ${ }^{17}$ The precise scope of these exceptions, and the extent to which they are true exceptions at all, is open to some doubt, as is the relationship between them. The main thrust of Woolmington is clear; in the terms used by evidence lawyers, the burden of proof in a criminal case is on the prosecution throughout. In some cases, however, there is a burden of some sort, if not always a full burden of proof, on the defence. It is on these burdens that the rest of this article will focus. There are no less than four different types of burden that can lie on the defence. These are termed for the purposes of this

11 [1935] AC 462 at 481-482.

12 "The Presumption of Innocence" (1987) 38 NILQ 223 at 224.

13 Thus in his 1997 Hamlyn Lectures Lord Cooke of Thorndon argued that the English courts had subsequently found the Woolmington principle to be a useful excuse for their failure to temper other unjust features of the criminal law, notably the doctrine of strict liability: Turning Points of the Common Law (1997), pp 2848.

14 Smith, loc cit at n 12. Woolmington was applied in the Republic of Ireland by The People (Attorney-General) v McMahon [1946] IR 267 (CCA(I)) and The People (Attorney-General) v Quinn [1965] IR 366 (CCA(I)): see also The People (Attorney-General) v Oglesby [1966] IR $162(\mathrm{CCA}(\mathrm{I}))$.

15 Hardy v Ireland [1994] IR 550 (SC(I)).

16 Smith, op cit at n 12, p 223.

17 Above, n 11. 
article as follows: ${ }^{18}$ (1) the probative burden; (2) the evidential burden; (3) the tactical burden; and (4) the personal burden. As we shall see, the distinction between these different burdens is sometimes not easy to draw.

\section{The Probative Burden}

The first type of burden which the defence may have to bear is the probative burden, or "persuasive" burden as it is sometimes called. ${ }^{19}$ Where this arises, we see a true exception to Woolmington: in effect, the defendant has to prove his or her innocence. ${ }^{20}$ Lord Sankey refers to two cases where this burden arises in English law, one being the defence of insanity and the other "any statutory exception". ${ }^{21}$ The first of these has always been recognised as an exception to Woolmington, and it gives rise to no problems of analysis. ${ }^{22}$ The second exception can be further subdivided into two categories, "express" and "implied" statutory exceptions. The former category encompasses those statutory defences which expressly place a burden of proof on the accused. These are often found in regulatory offences, and in relation to firearms and explosives, offensive weapons, dangerous drugs and so on. Like insanity, they give rise to few if any problems of analysis.

The category of implied exceptions is more problematical. In England, section 101 of the Magistrates' Courts Act 1980 provides as follows:

"Where the defendant to an information or complaint relies for his defence on any exception, exemption, proviso, excuse or qualification, whether or not it accompanies the description of the offence or matter of complaint in the enactment creating the description of the offence or on which the complaint is founded, the burden of proving the exception, exemption, proviso, excuse or qualification shall be on him; and this notwithstanding that the information or complaint contains an allegation negativing the exception, exemption, proviso, excuse or qualification."

Similar provisions are to be found in Northern Ireland, ${ }^{23}$ in the Republic of Ireland, ${ }^{24}$ in Scotland ${ }^{25}$ and throughout the common law world. ${ }^{26}$ At first

18 Some of these labels are traditional: others are borrowed from other authors or invented for the purpose. As Sir Rupert Cross pointed out, there is nothing in the nature of an agreed terminology, so that it is not always clear as to the sense in which a particular term is being used by a writer or judge: Cross and Tapper on Evidence (9th ed, Butterworths, London, 1999) (“Cross and Tapper”), pp 107 108.

19 Cross and Tapper, $\mathrm{p} 108$.

20 The standard of proof here is on the balance of probabilities: Carr-Briant [1943] 2 All ER 156 (CCA(E)), The People (DPP) v O'Mahony [1985] IR 51 (SC(I)); Convening Authority v Doyle [1996] 2 ILRM 213 (CMAC(I)).

21 Above, $\mathrm{n} 11$.

22 See M'Naghten (1843) $10 \mathrm{Cl} \& \mathrm{~F} 200$ (HL(E)) at 210; Attorney-General v Boylan [1937] IR 449 (SC(I)); Doyle v Wicklow County Council [1974] IR 55 (SC(I)); Criminal Justice Act (NI) 1966, s 2(1).

23 Magistrates' Courts (NI) Order 1981, art 124.

24 County Officers and Courts (Ireland) Act 1877, s 78.

25 Criminal Procedure (Scotland) Act 1995, schedule 3 para 16.

26 Smith, op cit at n 12, p 223. 
sight, the provision may seem to relate merely to an esoteric issue of summary jurisdiction, but in fact it gives rise to problems on a much wider scale. The scope of section 101 and its relationship to Woolmington has already been the subject of extensive analysis by scholars, not least by Sir John Smith, ${ }^{27}$ and it is therefore unnecessary to give more than a bare summary in the present context. Though section 101 and its kindred provisions in other jurisdictions are in terms limited to cases where the offence is created by an "enactment", its origins lie in a common law principle going back to the seventeenth century, whereby certain matters which were thought to be peculiarly within the knowledge of the accused did not have to be pleaded and negatived in the indictment, but were left to be raised by the defence. ${ }^{28}$ The exact scope of this rule, and the extent to which it affected the burden of proof, is a matter which needs no further discussion in the present context. ${ }^{29}$ Suffice it to say that the English Court of Appeal in Edward ${ }^{30}$, the Irish High Court in Attorney-General v Duff ${ }^{31}$ and the House of Lords in Hunt ${ }^{32}$ all agreed that section 101 was paralleled by an equivalent common law principle ${ }^{33}$ which was not confined to summary trials but extended also to trials on indictment, ${ }^{34}$ since the burden and standard of proof could hardly vary depending on the court in which the case was being tried. ${ }^{35}$

There has been much discussion in the cases and elsewhere as to what constitutes an "exception, exemption, proviso, excuse or qualification". Obviously this will not be so where the accused is relying on a general common law defence such as duress, self-defence or provocation, where the law as we shall see clearly puts the burden of proof on the prosecution. ${ }^{36}$ The situation is more problematic where the defence in question is a special one contained in a statute setting out the crime. Here the starting point of the analysis is the distinction between defences which negative one of the essential ingredients of the offence and those which set up other facts by way of confession and avoidance. ${ }^{37}$ As we shall see, this distinction is both controversial and a tricky one to draw. ${ }^{38}$ Even if it can be maintained, it does not conclude the matter, for the question is not merely one of grammar but of

27 Op cit.

28 The development of this rule was traced by Lawton LJ in Edwards [1975] 1 QB $27(\mathrm{CA}(\mathrm{E}))$ at 32-33.

29 See Zuckerman, "The Third Exception to the Woolmington Rule" (1976) 92 LQR 402.

30 [1975] 1 QB 27 at 31 and 36.

31 [1941] IR 406.

32 [1987] AC 352 at 369-373 and 385-386.

33 See Turner (1816) 5 M \& S 206 (KB(E)); Apothecaries' Co v Bentley (1824) C \& P 538 (Nisi Prius (E)); $R$ (Sheahan) v Justices of Cork [1907] 2 IR 5 (KBD(I)); Scott (1921) 86 JP 69 (CCA(E)); Oliver [1944] KB 68 (CCA(E)); The People (Attorney-General) v Shribman and Samuels [1946] IR 431 (CCA(I)); Putland and Sorrell [1946] 1 All ER 85 (CCA(E)); Minister for Industry and Commerce v Steele [1952] IR 304 (SC(I)); John v Humphreys [1955] 1 WLR 325 (QBD(E)); McGowan v Carville [1960] IR 330 (HC(I)); Robertson v Bannister [1973] RTR $109(\mathrm{QBD}(\mathrm{I}))$.

${ }^{34}$ Smith, op cit at n 12, p 231.

35 [1987] 1 AC 352 at 373 and 385.

36 Below, nn. 76-79.

37 Smith, op cit, p 230.

38 Below, n 95. 
policy. Thus it has been held that where the words of the statute do not clearly indicate upon whom the burden is meant to lie the court has to look to other considerations, such as the mischief at which the Act is aimed and practical considerations affecting the burden of proof; in particular, the ease or difficulty that the respective parties would encounter in discharging the burden. ${ }^{39}$ Thus in Hunt ${ }^{40}$ it was held that regulation 4(1) and Schedule 1 of the Misuse of Drugs Regulations 1973, which exempted from criminal liability the possession of any morphine preparation containing not more than 0.2 per cent of morphine, placed the burden of proof on the prosecution to show that the contents of the preparation in question exceeded the specified amount, and that it was not up to the defence to prove that they did not. Despite the structure of the provision, the matter was one upon which it was easier for the prosecution - who, after all, would normally have an analyst's report - to give evidence than the defence. The court should be slow, it was said, to conclude in the absence of the clearest words that Parliament had placed the burden of proof on the defence in an offence of this gravity. ${ }^{41}$

In sum, it seems that the burden of proof will be held to lie on the accused in relation to a statutory defence of this sort only where the defence in question can plausibly be described as an exception to a main head of liability prescribed by the statute, and then only where it relates to matters in relation to which it is reasonable to expect him to produce evidence rather than the prosecution. In the light of this, it may well be, as Tapper says, that the effects of Hunt are unlikely to prove so deleterious as its critics assert, nor so beneficial as its supporters may hope..$^{42}$

There is no injustice in a principle which compels the accused to produce evidence in support of a defence involving facts which are peculiarly within his own knowledge. Whether it is either necessary or desirable to go further and impose a full burden of proof is a different matter altogether. The validity of reverse onus provisions of this sort has been questioned in the Irish Republic in the light of Article 38.1 of the Constitution, whereby no person is to be tried on a criminal charge save in due course of law. In Hardy $\mathrm{v}$ Ireland $^{43}$ the applicant was charged under section 4 of the Explosive Substances Act 1883, which reads as follows:

"Any person who ... knowingly has in his possession. . . any explosive substance, under such circumstances as to give rise to a reasonable suspicion ... that he ... does not have it in his possession...for a lawful object, shall, unless he can show that he. . . had it in his possession ... for a lawful object, be guilty of felony"

39 Attorney-General v Duff [1941] IR 406 (HC(I)); People $(A-G)$ v Shribman and Samuels [1946] IR 431 (CCA(I)); Oliver [1944] KB 68 (CCA(I)); Putland and Sorrell [1946] 1 All ER 85 (CCA(E)); Nimmo v Alexander Cowan and Sons Ltd [1968] AC 107 (HL(S)).

40 [1987] 1 AC 352 (HL(E)).

41 Ibid at 378 (Lord Griffiths).

42 Cross and Tapper, 134.

43 [1994] IR 550 (SC(I)) 
Challenging the validity of this provision, the applicant argued that it required him to prove his innocence, and as such was contrary to Article 38.1. The High Court and the Supreme Court both rejected the application, but different reasons were given by the various judges involved in the case. According to Flood $\mathrm{J}$ in the High Court, section 4 did no more than place an evidential burden on the accused. ${ }^{44}$ In the Supreme Court, Egan and Murphy JJ conceded that the provision required the defence to prove a lawful object on the balance of probabilities, but said that such provisions did not necessarily infringe the Constitution. ${ }^{45}$ The question came up again in $O$ 'Leary v Attorney-General ${ }^{46}$ two years later. Here the accused was charged with IRA membership contrary to section 21 of the Offences Against the State Act 1939. Various documents emanating from the IRA had been found in his possession, and the prosecution sought to rely on section 24 of the Act, whereby such possession constituted evidence of membership "until the contrary is proved". Applying the presumption of constitutionality, whereby a statute of the Irish Parliament is to be interpreted if at all possible in a manner compatible with the Constitution, ${ }^{47}$ the Supreme Court unanimously held that section 24 did no more than place an evidential burden on the defence, since to impose a full burden of proof would have been contrary to Article 38.1. The upshot of this is that the use of the word "prove" in Irish legislation of this sort no longer necessarily imports a requirement that the defence be made out on the balance of probabilities. This is in line with the proposals of the English Criminal Law Revision Committee back in 1972, ${ }^{48}$ and does not seem, so far at any rate, to have caused any great problems in the administration of the law.

As we have seen, the presumption of innocence is also enshrined in Article 6(2) of the European Convention on Human Rights. A common lawyer might suppose that reverse onus provisions of this sort would inevitably be contrary to Article 6(2), but this is by no means the case. ${ }^{49}$ The matter has rarely been discussed in the jurisprudence of the Convention: firstly because questions of this sort have less relevance in the inquisitorial systems of continental Europe,$^{50}$ and secondly because the courts prefer to decide cases on an individual basis rather than judge the validity of legislation in the abstract. In Salabiaku v France ${ }^{51}$ the applicant was convicted of smuggling under Article 392(1) of the Customs Code, whereby persons found in possession of goods brought into France without being declared to Customs were presumed to be criminally liable unless they could prove a specific

44 Ibid at 559

45 Ibid at 566 (Egan J) and 568 (Murphy J).

46 [1995] 1 ILRM 259 (SC(I)); cf Oakes [1986] 1 SCR 103 (Supreme Court of Canada).

47 East Donegal Co-operative Livestock Marts Ltd v Attorney-General [1970] IR 317 (High Court). The basis of the argument is that Parliament must be presumed to have passed legislation that is compatible with the Constitution.

48 See the Eleventh Report of the Committee (Cmnd 4991, 1972), paras 137-142: Smith, op cit at n 12, pp 242-243.

49 See Lewis, The Human Rights Act 1998: Shifting the Burden” [2000] Crim LR 667.

50 Jacobs, The European Convention on Human Rights (1975), p.113.

51 (1988) 13 EHRR 379 (ECHR). 
event of force majeure by way of exculpation..$^{52}$ The European Court of Human Rights held that the presumption of innocence had not been infringed. This was in essence a crime of strict liability, and it was perfectly permissible under the Convention for Contracting States to penalise a simple or objective fact as such, irrespective of whether it resulted from criminal intent or from negligence. ${ }^{53}$ Moreover, presumptions of fact or of law were a feature of every legal system, and whilst Contracting States were obliged under the Convention to confine them within reasonable limits, ${ }^{54}$ there was nothing in the present case to show that the courts had applied the contested provision in a manner incompatible with the presumption of innocence. ${ }^{55}$ In $R P$ v United Kingdom, ${ }^{56}$ the Commission considered section 30(2) of the Sexual Offences Act 1956, whereby a man who lives with or is habitually in the company of a prostitute, or who exercises control, direction or influence over a prostitute's movements in a way which shows he is aiding, abetting or compelling her prostitution with others, shall be presumed to be knowingly living on the earnings of prostitution unless he proves the contrary. It was held that the use of this provision to convict the applicant did not infringe the presumption of innocence; rather, it merely created a rebuttable presumption of fact which it was open to the defence to disprove. Moreover, that presumption was not an unreasonable one to draw in the circumstances, given the difficulty of proving offences of this sort by direct evidence. ${ }^{57}$ The matter was considered more recently by the House of Lords in $R \vee D P P$, ex parte Kebilene. ${ }^{58}$ This was a case involving section 16A of the Prevention of Terrorism (Temporary Provisions) Act 1989, a complex provision which dealt with the possession of articles for purposes of terrorism and which contained several reverse onus provisions which the applicant contended were contrary to the Convention. In an exhaustive analysis of the law, Lord Hope said that provisions of this sort had to be judged in the light of three questions. What does the prosecution have to prove in order to transfer the onus? What is the burden on the accused; in particular, does it relate to something which is likely to be difficult for him to prove, or does it relate to something which is readily in his knowledge or to which he readily has access? What is the nature of the threat faced by society which the provision is designed to combat? ${ }^{59}$ It seems, therefore, that a balancing exercise is required, and that reverse onus provisions will not infringe the Convention, provided that the presumption created by the provision is a reasonable one in itself, can be rebutted by appropriate evidence, and is applied so as to give the accused the benefit of any doubt in the individual case.

52 Ibid at para 14

53 Ibid at para 27; Schneider v France (1993) 36 Yearbook ECHR 76 (Commission).

54 (1988) 13 EHRR 379 at para 28.

55 Ibid at para 30; Pham Hoang v France (1992) 35 Yearbook ECHR 181 (ECHR).

56 Decision 5124/71, 42 CD 135, 1972.

57 Decision 5124/71, at para 135.

58 [1999] 3 WLR 972: Lewis, op cit at n 49, p 671.

59 [1999] 3 WLR 972 at 998-999. 


\section{The Evidential Burden}

The prosecution have to prove the defendant's guilt, but this does not mean having to disprove every possible defence in advance. As Lord Devlin said in Jayasena $\mathrm{v} R$ :

"[Woolmington $\mathrm{v} D P P]$ does not mean, as the House made clear in subsequent cases, that a jury must always be told that before it can convict, it must consider and reject provocation and self-defence and all other matters that might be raised as an answer to a charge of murder. Some evidence in support of such an answer must be adduced before the jury is directed to consider it; but the only burden laid upon the accused in this respect is to collect from the evidence enough material to make it possible for a reasonable jury to acquit." 60

Here Lord Devlin is applying to the defendant in a criminal case the general principle whereby in a trial by jury a party may be required to adduce some evidence in support of his case, whether on the general issue or on a particular issue, before that issue is left to the jury. ${ }^{61}$ There must, in Wigmore's graphic phrase, be enough evidence to "get past the judge". ${ }^{62}$ Similarly, the defence will not be allowed to succeed on a submission of no case to answer on the grounds that the prosecution have not disproved selfdefence, duress, provocation and so on. Before these defences can come into play, a proper "foundation" must be laid, as it is said; there must be some evidence in the case, either from the accused or from some other witness, which points towards the defence in question. If there is none, the judge need not leave it to the jury.

The evidential burden has two effects, the first arising in the event of a submission of no case to answer and the second when the judge sums up to the jury. ${ }^{63}$ The former effect results from the existence of the evidential burden on a particular party; since two opposing parties cannot both bear an evidential burden on the same issue, ${ }^{64}$ the existence of an evidential burden on one side absolves the other side from having to produce evidence on that issue unless and until the burden is discharged. This is why a submission of no case to answer can be rejected in the circumstances discussed above. ${ }^{65}$ The latter effect, in contrast, concerns the discharge of the burden; once this happens, the party upon whom the burden lies is entitled to have the issue left to the jury. This is what is meant by "getting past the judge". In effect, the evidential burden acts as a filter to save the jury from having to consider baseless issues.

60 [1970] AC 618 (JCPC) at 623.

61 Cross and Tapper, $\mathrm{p} 122$.

62 J H Wigmore, A Treatise on the Anglo-American System of Evidence (1940), para 2487.

63 C R Williams, "Placing the Burden of Proof" in Well and Truly Tried: Essays on Evidence in Honour of Sir Richard Eggleston (1982), p 271.

64 Glanville Williams, "The Evidential Burden: Some Common Misapprehensions" (1977) 127 NLJ 156 at 158.

65 This is also the effect of the tactical burden, as we shall see: below, nn $89-90$. 
There is a very great difference between the evidential burden and the probative burden. It is not merely that the former requires proof to a certain standard and the latter the mere raising of a doubt, as is sometimes said. Rather, the two burdens are, as Glanville Williams says, radically different in function. The probative burden is about what the judge says: telling the jury when they may or may not find themselves satisfied as to a particular issue in the case. The evidential burden is all about what the judge does: refusing a submission of no case to answer, or allowing a defence to go forward to the jury. ${ }^{66}$ Nor need the probative and evidential burdens necessarily be on the same party. Sometimes they are; thus for instance in a criminal trial the prosecution is said to bear both the evidential and the probative burden with regard to the main elements of the crime, whilst in relation to the defence of insanity both burdens are on the defence. ${ }^{67}$ However, sometimes the evidential burden lies on the defence in the first instance, but the probative burden lies on the prosecution if the evidential burden is discharged. Thus, as we shall see, in relation to most general defences the accused bears the evidential burden, but if this is discharged the prosecution must prove beyond reasonable doubt that the defence is not made out.

Evidential burdens are not confined to the defence, or to criminal trials. In a civil case involving a jury, the plaintiff has to convince the judge that there is a case fit to go to the jury (the evidential burden), and then at the end of the day the jury must be satisfied on the balance of probabilities that the case is made out (the probative burden). ${ }^{68}$ In the same way the prosecution in a criminal trial has to discharge the evidential burden to avoid a successful submission of no case to answer, and must then go on to discharge the probative burden to win a conviction. ${ }^{69}$ In theory, the defence is in the same position as regards getting past the judge when they have the evidential burden; if the judge does not find the burden satisfied, the issue may be withdrawn from the jury. ${ }^{70}$ However, the practical effect of this is very limited, for it takes very little by way of evidence to discharge the burden in this situation. ${ }^{71}$ There is also a fundamental difference in the way the burden impinges on the defence. In a civil case, or where the prosecution fails to discharge the burden in a criminal case, the judge can truly in the words of Glanville Williams "censor the evidence" 72 by withdrawing the issue altogether from the jury. But the judge in a criminal trial cannot, even if he is brave enough to say that he is withdrawing a defence from the jury, ${ }^{73}$ direct them to convict. This means that one cannot be sure, even if a defence has been withdrawn from the jury, that they will not go ahead and consider it

66 Op cit at n 64, p 156.

67 Cross and Tapper, pp $116-117$.

68 C R Williams, op cit at n 63, p 280.

69 Cross and Tapper, $\mathrm{p} 116$.

70 Glanville Williams, "Evidential Burdens on the Defence" (1977) 127 NLJ 182.

71 Thus, for instance, an evidential burden on the defence can be satisfied by the exculpatory part of a "mixed" statement: Duncan (1981) 73 Cr App R 359 (CA(E)) (provocation); Hamand (1986) 82 Cr App R 65 (CA(E)) (self-defence); and see Sharp (1988) 86 Cr App R 274 (HL(E)).

72 Op cit at n 64, p 157.

73 As Tapper points out, judges will be reluctant to do this where there is even a scintilla of evidence to support the defence, not least because they fear the possibility of an appeal: Cross and Tapper, p 117. 
anyway; indeed, the judge's instructions may make them only all the more determined so to do. ${ }^{74}$

So when does the defence bear an evidential burden? Four different areas are identified by Glanville Williams: ${ }^{75}$ (1) cases where the defence has the burden of proof; (2) general defences; (3) cases where the prosecution are required to prove a negative averment, such as the lack of a licence or of lawful excuse; and (4) the defence of automatism. Of these by far the most important is the second category. Thus such defences as self-defence, ${ }^{76}$ duress $^{77}$ and provocation ${ }^{78}$ need not be left to the jury unless there is some evidence in the case worth considering, ${ }^{79}$ but if such evidence has been produced the jury must be told not to convict unless satisfied beyond reasonable doubt that the defence has not been made out. For this reason, provisions which merely place an evidential burden on the accused do not contravene the "due process" requirements of the Irish Constitution, ${ }^{80}$ and they give rise to no problems with the European Convention on Human Rights. ${ }^{81}$

Most of the defences to which this rule relates have been described as "confession and avoidance" defences. The accused is not denying any basic element of the crime, but is raising further matters by way of justification or excuse; in a nutshell, he is not saying "I didn't do it", but "I did do it, but. ... But in some cases a defence raised by the accused may deny an element of the crime charged. One example of this is Woolmington itself, where the defence was one of accident, which is no more than another way of saying that the necessary malice aforethought was lacking. Does the defence bear any sort of burden here too? This brings us on to the question of the "tactical" or "provisional" burden.

\section{The Tactical Burden}

There is some authority for saying that an evidential burden only rests on the defence in the "confession and avoidance" situation just described, where the

74 The hallowed principle of jury secrecy, backed up throughout the UK by the draconian provisions in section 8 of the Contempt of Court Act 1981, prohibits any research being done into the extent to which juries obey instructions given to them by the judge, and even prevents any enquiry by the courts into what goes on in the jury room. Perhaps this is just as well; it has been suggested recently by Sir John Smith that public confidence in the jury system would be unlikely to survive too much scrutiny of its workings: "Is ignorance bliss? Could jury trial survive investigation?" (1998) 38 Med Sci Law 98.

75 (1977) 127 NLJ 182

76 Lobell [1957] 1 QB 547 (CCA(E)).

77 Gill [1963] 1 WLR 841 (CCA(E)).

78 Mancini v DPP [1942] AC 1 (HL(E)).

79 It does not matter whether that evidence has been produced by the defence or by the prosecution. Nor does it matter whether the defence has been specifically argued for by counsel, or whether for tactical reasons, it has not been mentioned. If there is any evidence in the case to indicate that the defence in question might be available, the judge must draw it to the attention of the jury: see Doran, "Alternative Defences: the Invisible Burden on the Trial Judge" [1991] Crim LR 878.

80 O'Leary v Attorney-General [1995] 1 IR 254 (SC(I)); above at n 46.

${ }^{81} R$ v DPP, ex parte Kebilene [1999] 3 WLR 972 (HL(E)) at 990 (Lord Hope). 
basic elements of the crime charged are admitted but further facts are put forward which, if true, entitle the defendant to an acquittal. ${ }^{82}$ Where the defendant denies an element of the crime, it is said, there is not even an evidential burden to be discharged. ${ }^{83}$ Now, this cannot mean that there can never be any burden on the defence at all in this situation. Sir John Smith cites in this connection the American case of State v Horton, ${ }^{84}$ a case from North Carolina in which the defendant claimed that he thought he was shooting a turkey. If there was any evidence that this was so, well and good; the jury would have to be directed to acquit if they thought that there was a reasonable possibility that the defendant was telling the truth; but it would be absurd to allow a submission of no case to answer on a murder charge because the prosecution have not disproved in advance the possibility that the defendant might have thought he was shooting at a turkey. The fact of the killing itself will sometimes ${ }^{85}$ demand an explanation from the defendant. As Lord Sankey said in Woolmington itself, if it is proved that the conscious act of the prisoner killed a man and nothing else appears in the case, there is evidence upon which the jury may, not must, find him guilty of murder. ${ }^{86}$ The question then is why the jury may find him guilty, in the absence of any direct evidence of malice aforethought and there being, ex hypothesi, no evidential burden on the defence. The answer given by Glanville Williams and others is that in cases of this sort the defendant has a "tactical" or "provisional" burden. This has been described as the burden which is borne by a party after the other has discharged an evidential burden. ${ }^{87}$ In such a case it is wrong to say that he is obliged to call evidence in order to succeed, as would be the case if the evidential burden had been on him, for at the end of the day he will still win the case if the jury are not satisfied to the requisite standard. He is certainly under a risk of losing if he does not do so, but one cannot put it any more strongly than that. ${ }^{88}$

How does the effect of this "tactical" burden differ from that of the evidential burden? As we have seen ${ }^{89}$, the effects of the latter are seen at two stages in the trial, namely, when there is a submission of no case to answer and when the judge seeks to withdraw a defence from the jury. In the first case, there is no difference at all between the evidential and tactical burdens; if the defence bears either of them in relation to a particular issue they cannot submit that there is no case to answer on the ground that the prosecution have not led evidence to disprove that issue. In the second case, however, there is a difference; the judge may withdraw a defence from the jury if an

82 Morgan [1976] AC 182 (HL(E)) at 200 (Lord Cross): see Glanville Williams, op cit at n 64; C R Williams, op cit at n 63, pp 289-290.

83 Glanville Williams, op cit, p 157.

8451 SE 945 (1905), discussed by Smith, op cit at n 12, p 226.

85 Whether it does in any given case will depend of course on the manner of the killing. As Glanville Williams points out, there is all the difference in the world between proving a fatal traffic accident and proving that the defendant drove his car straight at the victim: op cit at n 64, p 158.

86 [1935] AC 462 at 480.

87 Cross and Tapper, $\mathrm{p} 113$.

88 In the words of Sir Alfred Denning, as he then was, he must call evidence or take the consequences, which may not [sic] necessarily be adverse: "Presumptions and Burdens" (1945) 61 LQR 379 at 380; Cross and Tapper, loc cit.

89 Above, nn $63-65$. 
evidential burden has not been met, but cannot do this in the case of a mere tactical burden. Thus it is said that a defence of provocation or of duress may be withdrawn from the jury, but not a defence of accident or mistake, since the latter defences go to negative the constituent elements of the crime charged. ${ }^{90}$

That the legal concept of the tactical burden exists cannot be denied, but the distinction drawn by Glanville Williams and others between defences upon which the accused bears the evidential burden and those where he merely bears the tactical burden has not met with universal acceptance. Thus it has been argued by Tapper that even where the accused raises a defence such as alibi or mistake there is no logical reason why he should not bear a full evidential burden, since he is raising a fresh specific issue within the general issue, and that on policy grounds there is something to be said for preventing the jury from considering these defences if no reasonable foundation for them exists. ${ }^{91}$ Nor does the distinction square with all the authorities. It is clear that the accused bears the evidential burden in relation to the defence of automatism, ${ }^{92}$ even though this is tantamount to a denial not merely of the mens rea but of the actus reus as well, and there are similar dicta in relation to mistake ${ }^{93}$ and to alibi. ${ }^{94}$ Moreover, the distinction between definitional elements of a crime and defences is one which has been rejected as unworkable by many eminent scholars. ${ }^{95}$ Whilst it may be true to say that the distinction in question is no more difficult than a lot of others that the law obliges us to draw, ${ }^{96}$ there are good reasons for not trying to do so unless we really have to.

We have just seen that the only distinction between a defence on which the accused bears the evidential burden and one where he bears the tactical burden is that in theory the judge can in the former case withdraw the defence from the jury if there is insufficient evidence to support it. But judges are understandably reluctant to do this in practice, and as we have seen the impact of evidential burdens on the defence in a criminal trial is a limited one. ${ }^{97}$ Given the artificiality of withdrawing defences from the jury when it is not possible to direct them to convict, it may be asked whether at the end of the day the distinction between the evidential and the tactical burden is one really worth drawing in this context.

90 Glanville Williams, op cit at n 64, p 158; C R Williams, op cit at n 63, p 289.

91 Cross and Tapper, $\mathrm{p} 118$.

92 Bratty v Attorney-General for Northern Ireland [1963] AC 386 (HL(NI)).

93 Sweet v Parsley [1970] AC 132 (HL(E)) at p 164 (Lord Diplock).

94 Johnson [1961] 1 WLR 1478 (CCA(E)).

95 See Stone, "Burden of Proof and the Judicial Process" (1944) 60 LQR 415; Zuckerman, "The Third Exception to the Woolmington Rule" (1976) 92 LQR 402 at 415. Even Glanville Williams himself eventually came round to the view that "what we think of as the definition of an offence and what we call a defence can only be regarded as depending largely upon the accidents of language, the convenience of legal drafting, or the unreasoning force of tradition": "Offences and Defences" (1982) 2 LS 233 at 256.

96 Smith, op cit at $\mathrm{n} 12, \mathrm{p} 230$.

97 Above at nn $70-74$ 


\section{The Personal Burden}

In none of the cases so far discussed is there any burden on the accused to give evidence in person. Whether the burden on the defence is probative, evidential or tactical it can be discharged either by the accused in person, or by other defence witnesses, or even by admissions elicited from the prosecution witnesses in cross-examination. The defendant has never been obliged in the common law system to give evidence; indeed, he was not even entitled to do so until relatively recent times. ${ }^{98}$ But now that the accused can give evidence, can adverse inferences be drawn if he fails to do so? The extent to which a court or jury could do this at common law was open to argument, ${ }^{99}$ but the matter was put on a statutory footing in Northern Ireland by article 4 of the Criminal Evidence (NI) Order 1988, which was followed in England by section 35 of the Criminal Justice and Public Order Act 1994. The effect of these provisions is to allow for a court or jury to draw "such inferences as appear proper" from a defendant's failure to testify without good reason. No particular label has been given by the commentators to the burden thus placed on the accused, but it may conveniently be called the "personal" burden.

The legislation gives no indication as to what inferences are "proper" in this context, but it was held by the House of Lords in Murray v DPP 100 that the scope of the statutory provision is wider than that of the old common law, and that the drawing of adverse inferences is not confined to the drawing of specific inferences from specific facts, but can include in an appropriate case the general inference that the accused is guilty as charged. The only limitations to this are that a defendant cannot be convicted purely on the basis of the statutory inference; ${ }^{101}$ indeed, it has been held that there is no scope for drawing the inference at all unless the prosecution has made out a prima facie case against the accused. ${ }^{102}$ This means a case strong enough to go to the jury, so if there is no case to answer, the statutory inference can never come into play. ${ }^{103}$

98 The prohibition on the accused giving evidence was removed in England and Wales by section 1 of the Criminal Evidence Act 1898, in the Republic of Ireland by section 1 of the Criminal Justice (Evidence) Act 1924, and in Northern Ireland by section 1 of the Criminal Evidence Act (NI) 1923.

99 See Bathurst [1968] 2 QB 99 (CA(E)); Mutch (1973) 57 Cr App R 96 (CA(E)); Sparrow [1973] 1 WLR 488 (CA(E)); Martinez-Tobon [1994] 1 WLR 388 (CA(E)).

100 [1994] 1 WLR 1. This was a case on the Northern Ireland provision, article 4 of the Criminal Evidence (NI) Order 1988.

101 Criminal Evidence (NI) Order 1988, art 2(4); Criminal Justice and Public Order Act 1994, s 38(3).

102 Cowan [1996] QB 373 (CA(E)), affirming the dicta of Lord Mustill in Murray v $D P P$ [1994] 1 WLR 1 (HL(NI)), at $\mathrm{p} 4$.

103 It is however suggested by Murphy (Murphy on Evidence, (6th ed, 1997) at p 423) that on the basis of section 38(3) (article 2(4) of the 1988 Order) a judge may ask whether the accused is prepared to give evidence before making a ruling as to whether there is a case to answer, and may take any refusal to do so into account in coming to a decision on the point. If this is right, the accused is hit with the proverbial "double whammy"; his silence is taken into account both in deciding whether he has a case to answer and then in deciding whether he has answered it. The legislation itself is ambiguous on this point, but such a result 
In formal terms, the changes made by article 4 and section 35 do not have much effect on the existing structure of exceptions to the Woolmington principle. The burden of proof is not affected; the prosecution still have to prove their case beyond reasonable doubt, with or without the aid of the statutory inference. ${ }^{104}$ The defendant is not even subjected to any evidential burden; as we have just seen, the prosecution probably still has to show a good case to answer without having any recourse to the statutory inference, ${ }^{105}$ and there is nothing in the legislation allowing a judge to withdraw defences from the jury on the grounds that the accused has not gone into the witness box. All that the statutory inference does is to strengthen the tactical burden which already existed on the accused when the prosecution has made out a prima facie case. Before the new legislation, the accused knew that he was at risk of conviction if he did not produce some evidence to challenge the prosecution case ${ }^{106}$, but it was not clear to what extent this required him to testify in person. Now he knows that if he does not do so the consequences are likely to be fatal to the defence.

Strengthening an already-existing tactical burden may not seem to be a matter of very great moment, but in practical terms the effect of this legislation is profound. In effect, the prosecution need no longer necessarily prepare a case which will prove the defendant's guilt beyond all reasonable doubt; they can simply present a prima facie case, and then rely on the accused to make up the difference. If he goes into the witness box, they can elicit damaging admissions from him in cross-examination. ${ }^{107}$ If he does not, they can invoke the statutory inference. Either way, they are using the accused to do their job for them. We are a long way from Woolmington here. As Jackson argues, the traditional conception of the accusatorial criminal trial demands not so much an inquiry into the guilt of the accused as a demonstration of that guilt by the prosecution. ${ }^{108} \mathrm{He}$ adds that it is surely inconsistent with that principle to expect the accused to contribute to that demonstration, or to allow his refusal to participate in the trial by testifying to play a part in the proof of his guilt. All in all, the personal burden may make little difference to the law in theory, but in practice it is probably the most significant of all the exceptions to the Woolmington principle. ${ }^{109}$

There is no equivalent provision in the Irish Republic, which is hardly surprising given the constitutional significance of the so-called right of silence in that jurisdiction. ${ }^{110}$ According to the analysis of Costello $\mathrm{J}$ in

would be clean contrary to the proposals of the Criminal Law Revision Committee, upon which the legislation was based: see Cmnd 4991 (1972) para 111, and the observations of Lord Mustill in Murray cited above.

104 This is made clear by the English Court of Appeal in Cowan [1996] QB 373.

105 Though see $\mathrm{n} 103$ above.

106 Above, $\mathrm{n} 88$.

107 Bingham [1999] 1 WLR 598 (HL(NI)).

108 "Inferences from Silence" (1993) 44 NILQ 103 at $\mathrm{p} 108$.

109 In this context Peter Murphy's trenchant comments on the 1994 Act are well worth reading: op cit at $\mathrm{n} 103$, pp xiii-xiv.

110 See The People (Director of Public Prosecutions) v Quilligan [1986] IR 495 (SC(I)). Costello J in Heaney v Ireland [1994] 3 IR 593 (HC(I)) bases the right on the "due process" provisions of Article 38.1, but in the Supreme Court in that case Flaherty J preferred to base it on Article 40.6.1 and the right to freedom of expression: [1996] 1 IR 580. 
Heaney $\mathrm{v}$ Ireland, ${ }^{111}$ the common law right of silence embraces two discrete immunities against self-incrimination, the first being the immunity of the suspect in the context of the investigation, and the second being the immunity of the accused in the context of the trial. ${ }^{112}$ Obviously it is the second of these that is of most significance in the present context. Costello $\mathrm{J}$ explains this immunity as having developed out of the objections taken by the common law courts to the abuses arising from procedures involving the judicial interrogation of accused persons, and points out that it has been long established in the common law world and has been a basic concept of criminal law trials in the Irish criminal process for many years. ${ }^{113}$ It is an immunity enshrined in the Fifth Amendment to the United States Constitution, in the United Nations International Covenant on Civil and Political Rights, ${ }^{114}$ and in the jurisprudence of the European Convention of Human Rights. ${ }^{115}$

Given the tremendous significance of the right of silence in the common law system, it is not surprising that the provisions discussed above were vigorously challenged before the European Court of Human Rights in Murray v United Kingdom ${ }^{116}$ There the applicant was convicted of terrorist offences before a judge sitting alone under section 7 of the Northern Ireland (Emergency Provisions) Act 1978. ${ }^{117}$ In giving reasons for the conviction as required by section $7(5)$ of the Act, ${ }^{118}$ the judge said that he had drawn adverse inferences under the Criminal Evidence (NI) Order 1988, both from the applicant's failure to answer police questions and from his failure to testify at the trial. The applicant had been denied access to a solicitor for the first 48 hours of his detention, and it was held by the ECHR that this factor, taken together with the drawing of adverse inferences from his silence under questioning, amounted to the denial of a fair trial under Article 6(1) of the Convention. ${ }^{119}$ In relation to the right of silence generally, the Court made it clear that, though not specifically mentioned in the Convention, the right to remain silent under police questioning and the privilege against selfincrimination were both recognised international standards which lay at the heart of Article $6{ }^{120}$ However, these standards were not absolute. Whilst it would be incompatible with Article 6 to base a conviction solely on the silence of the accused or on his refusal to answer questions or give evidence, where a situation clearly called for an explanation such silence could legitimately be taken into account in assessing the persuasiveness of the prosecution evidence. ${ }^{121}$ In the present case, given the safeguards provided by the legislation, ${ }^{122}$ the inferences reasonably drawn against the applicant

111 See above.

112 [1994] 3 IR 593 at 603-604.

113 Ibid.

114 See Article 14.8(3)(g).

115 See Article 6.1 of the Convention, as interpreted in Funke v France (1993) 16 EHRR 297 (ECHR).

116 (1995) 19 EHRR 193.

117 See now section 75 of the Terrorism Act 2000.

118 See now Terrorism Act 2000, s 75(7).

119 (1995) 19 EHRR 193 at paras $66-68$.

120 Ibid, paras $44-45$.

121 Ibid, para 47.

122 Ibid, para 48. 
did not of themselves infringe either the presumption of innocence or his right to a fair trial. ${ }^{123}$ It is not without significance that as we have seen this was a trial before a judge sitting alone, who is obliged to give reasons for a conviction. Had a jury been involved, the outcome of the case might well have been different. ${ }^{24}$

\section{REFORM OF THE LAW}

Woolmington v DPP was decided over sixty years ago, and it would not be reasonable to expect its precepts to be set in stone for all time. But the case is one of such fundamental constitutional importance that we should at least expect any departure from it to be properly thought through and justified by the most rigorous analysis. Unfortunately this is far from being so, partly because some of the exceptions to Woolmington are older than the case itself, and partly because the sheer complexity of this branch of the law makes it difficult to see the wood for the trees. Even so, reform of the law in this area is no mere technical matter, but should depend on principle. Four basic questions need to be answered in this context.

The first question is whether a jury or other finder of fact should be expected to convict when it is of the opinion that as likely as not the accused is innocent. There can surely be only one answer to this question, but if it is accepted it would mean the abolition of all probative burdens on the defendant. The main argument in favour of imposing a burden of proof on the defence is that such burdens relate to matters of which the defendant has the best knowledge, and that the law would be unenforceable if such matters had to be proved by the prosecution in the normal way. ${ }^{125}$ But this is a fallacy; ${ }^{126}$ certainly it is an argument for imposing some sort of burden on the defence, but there is no reason why this has to be a full burden of proof. It is for this reason that the Criminal Law Revision Committee recommended as long ago as 1972 that all probative burdens on the accused be converted into mere evidential burdens. ${ }^{127}$ This is currently the position under the Irish Constitution, and no problems seem to have been caused in the administration of the law. ${ }^{128}$

The second question is whether the judge should be entitled to withdraw defences from the jury if they are not backed by sufficient evidence. The arguments are more evenly balanced here. It is argued by Tapper that there is something to be said for preventing the jury from considering the possibility of defences which lack any reasonable foundation, ${ }^{129}$ and that the

123 Ibid, para 54.

124 See Condron v United Kingdom [2000] Crim LR 679(ECHR) and commentary.

125 See Ewens [1967] 1 QB 322 (CCA(E)) at 473 (Melford Stevenson J).

126 See the Eleventh Report of the Criminal Law Revision Committee (Cmnd 4991, 1972), paras 137-142, and the comments of Davitt $\mathrm{P}$ in McGowan v Carville [1960] IR $330(\mathrm{HC}(\mathrm{I}))$ at 337.

127 As Smith points out, these provisions fell by the wayside not because of any intrinsic flaws but because of the controversy over the other recommendations of the Committee with regard to the right of silence: op cit at $\mathrm{n} 12, \mathrm{p} 242$. It is one of the ironies of legal history that the latter provisions have now come into effect but not the former.

128 Above, $\mathrm{n} 48$.

129 Cross and Tapper, $\mathrm{p} 118$. 
mere facile mouthing, in the words of Lord Morris, ${ }^{130}$ of some easy phrase or excuse should not be enough to place a duty on the jury to consider a particular issue. As against this we have seen ${ }^{131}$ that the practical effect of withdrawing a defence from the jury may not amount to very much, given that the law knows no such thing as a directed conviction. There is also a fundamental point of principle at stake here. Allowing a judge to withdraw a defence from the jury is open to the same criticism as was levelled by Lord Sankey against the prosecution case in Woolmington; it is tantamount to allowing the judge to decide the case and not the jury, which is not the common law. ${ }^{132}$ Should such a fundamental constitutional principle as that of trial by one's peers be watered down for the sake of convenience and tidiness? After all, if a jury is trusted to deliver a true verdict on the evidence, ${ }^{133}$ it can surely be trusted to reject baseless defences. If this argument is accepted, it leads to the surprising conclusion that the Criminal Law Revision Committee did not go far enough in proposing that probative burdens should be converted into evidential burdens. It may be that there is no need even for an evidential burden on the accused in this sort of case.

The third question is whether the prosecution should be obliged to negative in advance any possible defence that the accused might raise, at the risk of a successful submission of no case to answer if this is not done. Clearly this would be absurd, and there must therefore be some sort of burden on the accused here. But it need not be a burden of proof, or even an evidential burden. All that is needed is a rule placing a tactical burden on the defence not only in relation to defences in the strict sense but also where there is a denial of mens rea; indeed, the tactical burden should lie on the accused in relation to all matters peculiarly within his or her knowledge. ${ }^{134}$

This is probably already the law, and it involves no injustice to the accused; as we have seen, all that a tactical burden prevents is an unmeritorious submission of no case to answer. ${ }^{135}$ At the end of the day, the jury will still have to consider the issue, and will have to be satisfied beyond reasonable doubt before they may convict.

The fourth question relates to the existence and scope of what we have termed the personal burden. This is a more difficult issue, for questions about the scope of the so-called "right to silence" are as much political as legal. Certainly there is a lot of force in Bentham's famous aphorism that innocence invokes the right of speaking as guilt invokes the privilege of silence, ${ }^{136}$ and there can be no doubt that the right of silence has been a boon and a blessing to rogues and blackguards of all kinds. But that is the nature of fundamental rights; if they are only to be invoked in deserving cases, they are utterly worthless. ${ }^{137}$

130 Bratty v Attorney-General for Northern Ireland [1963] AC 386 (HL(NI)) at 417.

131 Above at nn $70-74$.

132 [1935] AC 462 at 480.

133 Whether such trust is justified is a different matter: see Smith, op cit at $\mathrm{n} 74$.

134 This is a very ancient principle, as we have seen (above at $\mathrm{n} 28$ ).

135 Above, nn 89 - 90.

136 See Gilbert (1977) Cr App R 237 (CA(E)) at 243; Jackson, op cit at n 108, p 110.

137 As Sir Thomas More says, in Robert Bolt's play A Man for all Seasons, even the Devil himself must have the benefit of law: see Murphy, loc cit at n 109. 
At the beginning of this paper it was said that Woolmington v DPP was one of those leading cases which, so far from settling the law once and for all, led to continuing discussion and debate. The debate about the presumption of innocence is one which needs to be carried on not only in the courtroom but in the wider political sphere, for the principles laid down in Woolmington are not mere "lawyer's law"; on the contrary, they go to the heart of our historic constitutional liberties. 